УДК 82.091

DOI: $10.17223 / 24099554 / 8 / 8$

\title{
Л.Н. Сарбаш
}

\section{ИНОНАЦИОНАЛЬНОЕ В РУССКОЙ ЛИТЕРАТУРЕ И ПУБЛИЦИСТИКЕ ХІХ В.: РЕЦЕПЦИЯ ПОЛИЭТНОКОНФЕССИОНАЛЬНОГО ПОВОЛЖЬЯ В ТВОРЧЕСТВЕ РУССКИХ ПИСАТЕЛЕЙ}

\begin{abstract}
В статье анализируется инонациональное в русской литературе и публицистике XIX в., рецепция полиэтноконфессионального Поволжья в характерных проявлениях этнографизма. Исследуется репрезентация нерусского, архетипь национального сознания, обычаи и обряды волжских народностей в изображении русских писателей.

Ключевые слова: инонациональное, русская литература XIX в., творческая рецепция, полиэтноконфессиональное Поволжье, этнографизм, локальные культуры.
\end{abstract}

Девятнадцатое столетие - время активного роста русского самосознания, актуализировавшего в литературе вопросы соотношения «своего» и инонационального - «иного», «другого». Одно из знаковых явлений эпохи - формирование и закрепление образа нерусского, и не только в традиционном аспекте русско-европейского взаимодействия в характерной дихотомии «Россия - Европа», «Восток Запад». В условиях этнического многообразия Российской империи русские писатели обращались к «внутренним» народам, к «духовной множественности» (Д. Лихачев) российского бытия. Русская литература в русле общей культурной тенденции эпохи (изучение России в историко-географическом, экономическом, этнографическом направлении и осознание ее как государства-империи, населенного многочисленными народностями) вводила в свое эстетическое пространство инонациональные миры, «осваивала» различные российские «инокультуры», создавала представление о «народах разноязычных», составляющих «Русскую землю» (В.И. Даль). Рецепция инонационального, жизни и верований нерусских народностей Волги - творческое воплощение поликультурного и этноконфессио- 
нального российского пространства, изображение которого расширялось в творческом процессе от десятилетия к десятилетию.

Поволжье представляло собой большое этноконфессиональное смешение народов, по меткому определению писателя Евгения Чирикова, это «великий Ноев ковчег» России, где вместе собрались все народы Европы и Азии и «все их боги, злые и добрые, со всеми чадами и домочадцами: великоросс, малоросс, татарин, чуваш, черемисин, мордвин, немец, еврей, персиянин, калмык... Христиане разных толков, последователи Будды, Магомета, грозного ветхозаветного Иеговы, Заратустры, первобытные язычники» [1. C. 95]. Писатель отмечает, что по прошествии веков на Волге мирно уживаются "разноплеменные народы», происходит взаимопроникновение народных миросозерцаний: «русский» бог «Никола-угодник сделался «Праведным Судьей» у чуваша-язычника, а гору Богдо, священную гору калмыка-буддиста, русский мужик называет Святою горою и снимает перед ней набожно шапку!» [Там же. С. 96].

Имагология российского пространства, «этнография психологическая» (Н. Надеждин) в полной мере проявляется в русской литературе XIX в., которая участвует в «освоении» инонациональной почвы российской действительности. Специфика жизненного уклада, обрядовая сторона жизни, религиозно-мифологические верования, поэтическое творчество нерусских народов Поволжья - чувашей, мордвы, вотяков (удмуртов), черемисов (марийцев), татар, башкир, малороссов («запорожцев за Волгой»), немцев, калмыков - появляется в творчестве русских писателей: в многочисленных заметках, в литературноэтнографических статьях, в идейно-художественной системе сочинений В.В. Измайлова, А.Ф. Воейкова, М.И. Невзорова, Д.В. Давыдова, Ф.Н. Глинки, А.Ф. Раевского, Т.С. Беляева, П.М. Кудряшева, И.И. Железнова, И.В. Селиванова, Н.Я. Аристова, А.Ф. Леопольдова, А.С. Пушкина, А.И. Герцена, И.И. Лажечникова, С.Т. Аксакова, И.С. Аксакова, В.И. Даля, М.В. Авдеева, А.К. Толстого, П.И. Мельникова-Печерского, А.А. Потехина, А.Н. Островского, С.В. Максимова, А.Ф. Писемского, Ф.Д. Нефедова, Н.С. Лескова, М.Е. Салтыкова-Щедрина, Г.И. Успенского, К.К. Случевского, Н.Д. Телешова, Л.Н. Толстого, Д.Н. Мамина-Сибиряка, Н.Г. ГаринаМихайловского, В.Г. Короленко, Вас.Ив. Немировича-Данченко, А.А. Коринфского, А.П. Валуевой и многих других.

Репрезентация инонационального в русском литературном процессе XIX в. предстает в нескольких направлениях: нерусское как 
религиозно-мифологическая этнография - обряды и обычаи, религиозно-мифологические верования; нерусское в типической характерологии времени как социальная этнография; нерусское как осмысление духовно-нравственного опыта и ценностного мира других народов.

Инонациональная картина бытия передается русскими писателями через архетипы национального сознания, русский и нерусский фольклор: легенды, исторические и топонимические предания, обрядовые песни раскрывают этнокультурные особенности, духовнонравственные идеалы многочисленных народов Поволжья. Фольклор как явление художественного синтеза проявляет в литературном творчестве русских писателей разнообразные поэтические начала. М.М. Бахтин отмечал, что одна национально-культурная традиция становится ярче через призму восприятия другой, именно тогда видится отличие от «своей» и своеобразие «иной»: «...чужая культура только в глазах другой культуры раскрывает себя полнее и глубже» [2. C. 354].

Одним из первых писателей, обратившихся к изображению иноэтнических явлений Российского государства, жизни и быта нерусских народностей, был писатель-этнограф В.И. Даль. Башкирская тема особенно широко представлена в творчестве Даля. Будучи чиновником особых поручений при губернаторе В.А. Перовском, писатель изъездил практически всю Оренбургскую губернию, интересуясь жизнью и поэтическим творчеством населяющих ее народностей, собрал много фольклорных и лингвистических материалов. На основе легенд, преданий, бытописания башкир и других национальностей огромного края Далем были написаны многочисленные статьи и созданы художественные произведения, связанные с жизнью русских и «коренных обитателей» Оренбуржья: «Замечания о башкирцах», «О кумысе», «Скачка в Уральске», «Скачки в Уральске и Оренбурге», «Охота на волков», «Башкирская русалка», «Полунощник», «Уральский казак», «Осколок льду», «Бикей и Мауляна», «Майна», «Новые картины русского быта» («Обмиранье»), «Рассказ об осаде крепости Герата». Повесть В.И. Даля «Башкирская русалка» создана на фольклорном материале: в ее основе, как отмечает М. Рахимкулов, древнейшее эпическое сказание о ЗаяТуляке и Хыу-Хылу [3. С. 462].

Художественным способом воссоздания нерусского является мифологическая характерология: при описании природы Башкирии наблюдается органическое соединение конкретного географическо- 
го описания местности - топонимов, гидронимов, цифровых параметров пещер - с поэтической башкирской мифологией, архаическими этнологическими сказаниями и топонимическими легендами. Реальные исторические и этнического характера сведения «соседствуют» в повествовании, тесно переплетаются и «сращиваются» с преданиями устного народного творчества, с многочисленными башкирскими легендами - о каменной собаке в пещере Шуллюганьташи; о жилище дью-париев, находящихся в подземной мельнице Тименетау; об озере Елкикичкан - царстве могучего падишаха водяных, наградившего смелого Кунгрбая табуном лошадей. Аналогичная легенда реализуется и в сказе: отец русалки дает Зая-Туляку на обзаведение табун отличных, выплывших из озера коней, от которых произошла, как замечает рассказчик, знаменитая порода димских башкирских лошадей. Характеристика родовых знаков башкир сопровождается поэтическими преданиями о Чингис-хане [4. C. 330-331].

В.И. Даль разнообразен в способах художественной инкорпорации этнографического материала. Башкирское создают этнорегионализмы тюркского происхождения, обозначающие разные стороны национальной жизни (чапан, юрта, чебызга-курай, кумыс, крут, сабы, турсук, тамга, уран); маркером этнического является национальный костюм, который подробно описывается; актуализатором башкирского выступают названия демонологических существ (шайтан, дью-пари, джин, подводный падишах, див). Этнографическая насыщенность, достоверность этнических деталей, «живая, внутренняя верность действительности» (В.Г. Белинский) - характерная особенность писателя в изображении инонациональной жизни. В сюжетно-композиционной системе «Башкирской русалки» происходит объединение разнородных повествовательно-жанровых элементов, в результате чего и создается яркая инонациональная мифологема. Можно со всей определенностью сказать, что В.И. Даль явился не только родоначальником русской литературно-этногра-фической школы, но и основоположником ее инонационального направления.

Начало формированию инонациональной этнографии в русском литературном процессе XIX в. было обозначено произведениями П.М. Кудряшева («Прощание башкирца с милой», «Песнь башкирца перед сражением», «Песнь башкирца после сражения») и Т.С. Беляева («Куз-Курпяч, Башкирская повесть, писанная на Башкирском языке одним курайчем и переведенная на Российский в до- 
линах гор Рифейских, 1809 года», «Песнь Курайча Рифейских гор»). Лирический цикл П.М. Кудряшева об участии башкир в Отечественной войне 1812 г. - вольный перевод народных башкирских песен. Русский писатель вводит образы мусульманской культуры, которые придают изображаемому национальный колорит: башкир клянется священной книгой «Алкораном», «пророком божиим» Магометом; ожидающим сражения ниспослано благословение Аллаха; смерть дарует погибшему рай, который предстает в кораническом контексте грядущих наслаждений:

Вам счастье, радости в раю;

Там гурий девственных лобзанье,

Их ароматное дыханье,

Объятия, улыбка, взгляд -

Блаженством храбрых наградят! [5. С. 200].

П.М. Кудряшев намечает пути литературного соположения разных национально-культурных традиций. Башкирский цикл П.М. Кудряшева показателен как значимый фактор художественного развития: в русском творческом процессе появляется произведение, транслирующее инонациональный фольклор и воспроизводящее события 1812 г. от лица героя-инородца. Важно и обращение русского поэта к башкирской народной песне: по существу, это было началом собирания башкирского народного творчества.

«Песнь Курайча Рифейских гор» Тимофея Беляева, повествующая об участии башкирских воинов в войне 1812 г., представляет собой фольклорную стилизацию: в произведении присутствуют образы и мотивы башкирского народного творчества; башкиры определяются в русле устно-поэтической традиции как народ, «семью зовущийся родами» (по преданию, на основе царской грамоты башкиры поделили земли на семь родов); Рифейские горы (древнее название Уральских гор) предстают как родина башкир, битва уподобляется свадебному пиру «тую»; встречаются башкирские слова и выражения, которым даются авторские пояснения - «батырь», «туйгун», «туй», «курайча» и др. «Песнь Курайча Рифейских гор» представляет собой мифопоэтическое осмысление исторического события, которое предстает в эсхатологическом масштабе как вселенская битва божественных и сатанинских сил - древнего мусульманского Дадьжала («ложного мессии»), которого Аллах низвергнул в бездну, кого христиане называют антихристом. Курайча объясняет башки- 
рам - обитателям Рифейских гор - духовное значение, сакральный смысл 1812 г.:

Народ! Внемлите весть благую,

Урус погану рать и злую

Попрал, стоптал, под ноги смял.

Джигиты наши подоспели,

Как снежны бури, налетели,

И враг на Запад побежал [6. С. 499].

В башкирской мифопоэтической традиции (Урал «страна семи родов») трактуется и результат победы: из великого испытания рождается «осьмой род» - новое сообщество народов, в которое вошли башкиры-«семиродцы»:

Из дальних зрю толпами

Аулов едущий народ,

Семью зовущийся родами,

В осьмой присвоенный им род [Там же. С. 500].

Обращение к инонациональной этнографии и фольклору как характерная художественная тенденция времени активно заявляет о себе в литературе и публицистике XIX в. - в сочинениях В. Зефирова («Рассказы башкирца Джантюри. Из воспоминаний о войне с французами»), И.И. Лажечникова («Некоторые поверья Мордвы»), П.И. Мельникова-Печерского («Общественные моления эрзян», «Эрзянская свадьба», «Мокшанская свадьба», «Очерки Мордвы»), И.В. Селиванова («Мордва»), М.В. Авдеева («Горы», «Поездка на кумыс»), А.Ф. Писемского («Татары», «Астраханские армяне», «Калмыки»), С.В. Максимова («Куль хлеба и его похождения», «Край крещеного света»), Д.Н. Мамина-Сибиряка («Баймаган», «Лебедь Хантыгая», «Слезы царицы», «Майя», «Ак-Бозат»), Ф.Д. Нефедова («Зигда», «Ушкуль»), Н.Д. Телешова («Сухая беда», «Живой камень»), Н.Г. Гарина-Михайловского («В сутолоке провинциальной жизни», «Зора»), А.М. Горького («Немой», «Знахарка») и многих других.

Инонациональное направление русской этнографической школы XIX в. продолжает и развивает С.В. Максимов. Русский писатель обратился к осмыслению национального бытия, созданию этнопсихологических образов многочисленных российских народностей. В четырех частях цикла «Край крещеного света» С.В. Максимов одним из первых создает целостное художественно-этнографическое 
изображение российских народов, отмечая их национальную специфику и черты самобытной культуры. Произведение предназначалось для народного чтения, написано простым и доступным языком и в дореволюционной России выдержало более девяти изданий. «Край крещеного света» преследовал и просветительскую цель: знакомство с национально-культурным своеобразием народов, составивших Российскую империю, приобщение читателя к духовным устоям многонационального Отечества.

Bce части книги построены по одному сюжетно-композиционному принципу: указывается численность того или иного народа и ареалы расселения, род занятий и уклад жизни, этнографическая характеристика - праздники, обычаи и обряды, обращается внимание на свойственные тому или иному народу древние религиозномифологические верования. С.В. Максимов работает в жанре очерка, отличительная черта которого - достоверность изображения: писатель отмечал, что в основе его произведений лежат только личные наблюдения, «голые факты, целостно взятые из жизни». Писатель видел большие возможности очерковых форм в художественном исследовании разнообразных сторон народной жизни в ее конкретике и бытописании. Изображая народы Поволжья, писатель отмечает их трудовое, культурно-историческое «присутствие» в большом российском мире; создает этнические образы-«лица», связывая с каждой из народностей определенные общественно-культурные и национально-религиозные константы. Каждая глава снабжается эпиграфом - русскими и нерусскими пословицами, в которых содержится своеобразная этноконстанта в определении национального.

Черемисы (марийцы) селились в глуши, это «лесной народ», и русский мужик находит для этого соответствующее определение: «Первого черемиса леший родил, оттого они все в лесу сидят» [7. С. 49]. Чуваш определяется у русских собирательным именем «Василий Иванович», что объясняется у Максимова историческим преданием: иеромонах Вениамин Пуцек-Григорович крестил чувашей толпами и любил якобы давать им свое светское имя «Василий», а воспреемником был дьякон Иван Афанасьев. За определением чуваша как «Василия Ивановича» следует ироническая диалогическая сценка: «Поп Васька дома?» - «А кто там?» - «Я - Василий Иванович» [Там же. С. 55].

Писатель знакомит русского читателя с огромным поликультурным пространством Российской империи - укладом жизни, религи- 
озно-мифологическими верованиями, обычаями и обрядами нерусских народов, что было чрезвычайно значимо как в культурноисторической тенденции эпохи, так и в развитии русского литературного процесса. С.В. Максимов развивает этнографическое направление, осваивающее инонациональную типологию, преследующее цель изображения национально-культурного своеобразия нерусского. Иноэтнический материал актуализировал очерковую форму, использующую новые способы типизации, структурообразующим началом которых является этнографизм. Этнокультурной типологией обусловлен и принцип циклизации очерков, являющийся характерной особенностью произведения «Край крещеного света».

В произведениях русских писателей значимы инонациональные эпизоды, передающие локальные этнокультуры Поволжья. В идейно-художественной системе произведений М.И. Невзорова, В.И. Даля, С.Т. Аксакова, Н.С. Лескова, А.А. Потехина, Н.Д. Телешова, Н.Г. Гарина-Михайловского, В.Г. Короленко, Вас.Ив. НемировичаДанченко и многих других писателей нерусский текст не только создает этнопсихологический тип, иную национально-культурную традицию, но и помогает понять ментальность русского человека, специфику его национального характера и мировосприятия.

В повести Н.С. Лескова «Очарованный странник» русский Иван Флягин «заявлен» в ситуации взаимодействия с нерусским миром, в условиях полиэтнического жизненного пространства. Повествование об инонациональном ведется от лица героя, через призму восприятия которого и предстают нерусские: «чувашин», татары с их степными обычаями, люди «индийского бога» Талафы; однако повествовательный ракурс не мешает передаче нерусских реалий жизни. Инонациональное, в частности чувашское, предстает в своей национальной конкретике и самобытности: упоминается злое божество старой чувашской веры Киреметь, которому чуваши приносили жертвенные дары, Николай Чудотворец («Николач бок»), который в качестве «русского Бога» особенно почитался крещеными народами Поволжья.

В цикле Н.Г. Гарина-Михайловского «В сутолоке провинциальной жизни» выделяются своей яркостью и этнографической насыщенностью этнические эпизоды, в которых также предстает чувашская мифология: языческие боги - «добрый Тура», злой Ирик и весенний праздник Уяв, при изображении которого дается описание национального костюма и хоровода. В христианском погребе- 
нии Зораиба писатель отмечает присутствие черт древней чувашской обрядности: «Пекли блины, закатывали в них сальные свечи и бросали собакам. Грызлись собаки, хорошо грызлись, и веселые были похороны. Пьяные напились чуваши, пели песни» [8. С. 374]. В религиозных верованиях чувашей четко обозначена мифологема: умершие посещают устраиваемые поминки и принимают в них непосредственное участие: на могилу отливалось пиво, клались хлебные и мясные яства, которые съедались собаками. Хорошим знаком почитался у чувашей визг собак: это означало, что умершие явились на поминки и разделили с живыми трапезу.

В цикле Н.Д. Телешова «По Сибири», в повести «Сухая беда», одним из основных героев является инородец Максимка. Инонациональный обычай - чувашская «сухая беда» - становится сюжетной основой всего произведения. В повести Н.Д. Телешова, как и в рассказе В.И. Даля «Сухая беда», чувашская «тыпь шар» связывается с глубинным проявлением бытия - с народными нравственноэтическими представлениями о справедливости и правде, о наказании обидчика. Герой осознает, что «Хаяр-Кереметь» (злое чувашское божество старой веры) не властна над русским Кургановым. Максимка решается на «сухую беду», «тыпь-шар» - самоубийство, которое сделает Курганова несчастным на всю жизнь, заставит нравственно мучиться и приведет к смерти. Древнее чувашское «тыпь-шар» для героя прежде всего победа над «проклятым куштаном» Кургановым, долгая и мучительная нравственная гибель врага. В повести дается яркая картина жизни чуваша Максимки: его жизнь на родной Волге, обряд развода с женой - разрыв «сурбана», игра на шыбыре - народном музыкальном инструменте. Создавая нерусского персонажа, писатель выделяет лексически его речь, в качестве кодификатора этнического дает чувашские слова - «йомзя», «куштан», «хозя», «шыбыр», «пюремечи», «сурбан», «Кереметь», тепьпулдор, тамок хуран; приводит чувашское название Млечного Пути - «Дорога Диких гусей». Нерусское передает «иные» этнокультурные константы русского мира.

Бинарная оппозиция «русский - нерусский» предстает в произведениях писателей в характерной репрезентации: инонациональное «иное», «другое», но при этом не «чужое», часть русского мира. «Чувашские» эпизоды произведений Н.С. Лескова, Н.Г. ГаринаМихайловского, Н.Д. Телешова создают яркий образ поликультурного мира Волги. 
В русской литературе XIX в. следует выделить оригинальное структурно-жанровое образование (разновидность путевого очерка), которое можно определить как «путешествие по Волге», описывающее Волгу и ее природу, города и многочисленные народности, населяющие великую реку с ее верховья до «Букеевской Орды»: сочинения М.И. Невзорова («Путешествие в Казань, Вятку и Оренбург в 1800 г.»), Ф.Д. Нефедова («Этнографические наблюдения на пути по Волге и ее притокам»), А.Н. Островского («Путешествие по Волге от истоков до Нижнего Новгорода»), А.А. Потехина («Путь по Волге в 1851 г.», «С Ветлуги»), С.В. Максимова («Куль хлеба и его похождения»), В. Сидорова («По России. Волга. Путевые заметки и впечатления от Валдая до Каспия»»), А. Лепешинской и Б. Добрынина («Волга»), Вас.Ив. Немировича-Данченко («Великая река. Картины из жизни и природы на Волге»), А.А. Коринфского («Волга. Сказания, картины и думы») и многих других.

В «путешествии по Волге» календарное время и хронологический принцип классического путешествия заменяется пространственно-географическим топосом - Волгой. Хронотоп Волги как дороги-пути становится структурообразующим фактором волжского травелога, характерным свойством которого является этнографизм. В «Путешествии в Казань, Вятку и Оренбург в 1800 г.» М.И. Невзорова мусульманский контекст (пространное описание богослужения, тексты многочисленных молитв, эпиграфика, дающая экзистенциальные представления мусульманина о мироздании и человеке) создает яркий образ татарского мира Поволжья.

В многочисленных произведениях «путешествия по Волге» активно задействованы волжская мифология, русский и нерусский фольклор - песни, исторические легенды и предания. Вас.Ив. Немирович-Данченко в произведении «Великая река. Картины из жизни и природы на Волге» отмечает полиэтничность Поволжья, его культурно-национальное многообразие. Палуба парохода представляет собой интереснейшее зрелище, своеобразную «этнографическую выставку». Писатель дает антропологическую характеристику народностей, показывает своеобразие их национальной «физиономии»: славянские лица с «мясистыми» носами и скуластые, «монгольские» лица тюркских народов. Видятся писателем и ментальные черты: отмечается восточная сдержанность татар, которым трудно принять открытость, общительность, «громкость» русских женщин. 
Писатель изображает поликультурное пространство, предстающее в сопряжении различных национальных культур, особо отмечает разнообразную этническую характерологию Нижнего Поволжья:

Какая смесь одежд и лиц <..> Калмычки в красных платьях, гелюнг в желтой рясе. <..> какой-то скуластый и громадный монгол < ..> Начиная от Астрахани, вверх по Волге до Казани, затем по Волге до Соликамска <..> везде на пристанях, на лавках, на улицах встретишь татар $<\ldots>$ Между татарами и калмыками - солидные, медлительные хохлы, не изменившие на чужбине ни своему костюму, ни своему типу [9. С. 139].

В произведении представлен уникальный волжский синтез, в основе которого национальное многообразие и межэтническое взаимодействие как форма сосуществования национально-культурных миров. В путевом очерке Немировича-Данченко создается полиэтнический образ Волги как матери русского народа и нерусских российских этносов. В создании инонационального образа писатель активно использует русский и нерусский фольклор, легенды древней Волги - сказания о Скворце и Дятле, Бориславе, двенадцати инородческих богатыршах, бабе-«ватамане», Стеньке Разине, Жигулях, Девичьих горах. Писатель использует структурный параллелизм поэтических источников - мордовский и русский варианты легенды о плененной княжне во времена Булгарского царства. Фольклоризм как поэтическая характерология «путешествия по Волге», усложняющая сюжетно-жанровую систему произведения, способствует проявлению в очерковом повествовании эпической основы.

Особый интерес в русской литературе и публицистике XIX в. представляют произведения, связанные с рецепцией немцев Поволжья. Немецкий мир Волги предстает в сочинениях А.В. Салтыкова («Записки путешественника в Сарепту»), В.В. Измайлова («Путешествие в полуденную Россию»), А.Ф. Воейкова («Письмо из Сарепты», «Сарепта тихая, селение Христа!», «Путешествие из Сарепты на развалины Шерри-Сарая, бывшей столицы Золотой Орды»), А.Ф. Леопольдова («Несколько слов о колонистах», «Исторический очерк Саратовского края», «Поездка в Низовое Поволжье»), Я. Сабурова («Поездка в Саратов, Астрахань и на Кавказ»), Д.Л. Мордовцева («Сарепта»), И.С. Аксакова («Письма из провинции»), Н.С. Лескова (образ гернгутера в произведениях «Железная воля», «Островитяне», «Колыванский муж»), В. Сидорова («По Рос- 
сии. Волга. Путевые заметки и впечатления от Валдая до Каспия»), А. Лепешинской и Б. Добрынина («Волга»), Вас.Ив. НемировичаДанченко («Великая река: картина из жизни и природы на Волге»), А.А. Коринфского («Волга. Сказания, картины и думы») и многих других.

Дневники В.А. Жуковского, в которых он обращается к немецким реалиям Волги, также представляют несомненный интерес. Русские писатели создают яркий образ немецкого мира: культуры, национального уклада жизни, быта, акцентируя внимание на своеобразии самосознания немцев, ментальных черт народа. Немецкий мир Волги в изображении русских писателей - это пласт европейской германской культуры внутри огромного полиэтноконфессионального региона Поволжья. В контексте рецепции различных культурно-национальных констант - русской, татарской, калмыцкой - особенно ярко выделяется немецкая характерология.

В путевых заметках В.В. Измайлова «Путешествие в полуденную Россию» дается яркий запоминающийся образ Сарепты - процветающей немецкой колонии, основанной религиозной общиной братьев-гернгутеров в 1765 г. Философские поиски счастливого человека и идеального человеческого устройства писатель связывает именно с немецкой Сарептой, которая представляет собой «торжество человеческих обществ» и «семейство братии». В жизни сарептян В.В. Измайлов отмечает соединение естественности и культуры, привычки к физическому труду с духовно-нравственным началом жизнью сердца [10].

В.А. Жуковский в стихотворении «К Воейкову» («Добро пожаловать, певец...») создает образ Сарепты как «братство христиан простое», которое чрезвычайно близко его миросозерцанию. «Религией сердца» именует поэт литургию гернгутеров, а страстно ожидаемое воскресение Спасителя - эмоционально-лирическое переживание стихотворения:

Они смиренно к небесам

Возводят взор с мольбой хвалебной

И служат сердцем божеству,

Отринув мрак предрассужденья...

Что уподобим торжеству,

Которым чудо искупленья

Они в восторге веры чтут?..

И в трепете благоговенья 
Все братья той минуты ждут, Когда им звон - благовеститель

Провозгласит: воскрес Спаситель! [11. С. 98].

Русские публицисты акцентировали внимание на религиознонравственной стороне жизни немецких гернгутеров. А. Лепешинская и Б. Добрынин выделяли духовную жизнь сообщества гернгутеров как особую специфику, которую усматривали в высокой миссии Евангелического братства, стремящегося осуществить «истинно благочестивую жизнь» в духе христианства [12. С. 256]. Изображение немцев Поволжья, и особенно Сарепты, в русской литературной мысли XIX в., как правило, дается в общественноисторическом и культурно-этнографическом контексте сопоставления, посредством чего и происходит этнокультурная самоиндетификация.

В поэтическом цикле А.А. Коринфского «Волга. Сказания, картины и думы» возникает широкое этническое полотно Поволжья. В стихотворении «Немецкий рай» описываются процветающие немецкие поселения, давно появившиеся на российской земле, «фатерлянд»:

$$
\begin{aligned}
& \text { С Баронска до Сарепты } \\
& \text { И там, и здесь, и тут } \\
& \text { Столетние над Волгой } \\
& \text { Колонии цветут. } \\
& \text { Рейнштадт и Унтервальден, } \\
& \text { И Гакельберг... [13. С. 129]. }
\end{aligned}
$$

В цикле Коринфского в контексте обусловленного жизнью сопоставления возникает своеобразие волжских национально-культурных реалий: «соседство» национальных миров выделяет характерологию каждого, одно этническое своей спецификой и особостью оттеняет другое. Немецкое (европейское, «германское») на Волге сменяется степным калмыцким миром («азиятским»). Поэтическое соединение различных культурно-национальных констант создает яркий образ Волги, на необъятных просторах которой собран российский «Ноев ковчег». Немецкий текст русской литературы, существенно расширяя границы изображения российской действительности в ее культурноисторическом проявлении, передает этнокультурные константы национальной жизни немцев Поволжья и полихромный мир Волги как уникальное явление Российского государства. 
Творческая рецепция инонационального - новая смысловая и поэтическая содержательность русской литературы и публицистики XIX в., передающая картину нерусского бытия Поволжья, множественность российских культур, характеризующих космос русской цивилизации.

\section{Лuтература}

1. Чириков Е.Н. Волжские сказки // Собр. соч.: в 17 т. М., 1916. Т. 16. С. 94-120.

2. Бахтин М.М. Эстетика словесного творчества. М.: Искусство, 1986. 445 с.

3. Рахимкулов М. Комментарии к «Башкирской русалке» // Башкирия в русской литературе: в 6 т. Уфа: Башк. кн. изд-во, 1989. Т. 1. С. 462-463.

4. Даль В. (Казак Луганский). Полное собрание сочинений. СПб; М., 1897. Т. 7. $369 \mathrm{c}$.

5. Кудрямев П.М. Песнь башкирца после сражения // Вестник Европы. 1828. № 15. C. $198-201$.

6. Беляев Т.С. Песнь Курайча Рифейских гор // Поэты 1790-1810-х годов / вступ. ст. и сост. Ю.М. Лотмана. Л., 1971. С. 497-503.

7. Максимов С.В. Край крещеного света: в 4 ч. СПб., 1873. Ч. 2.82 с.

8. Гарин-Михайловский Н.Г. Собрание сочинений: в 5 т. М.: Гослитиздат, 1958. T. $4.722 \mathrm{c}$.

9. Немирович-Данченко Вас.Ив. Великая река. Картины из жизни и природы на Волге. СПб., 1902. 158 с.

10. Сарбаш Л.Н. Немецкий мир Волги: образ Сарепты в «Путешествии в полуденную Россию» В.В. Измайлова // Филологические науки. Вопросы теории и практики. 2016. № 6. Ч. 2. С. 25-27.

11. Жуковский В.А. Собрание сочинений: в 4 т. М.: Гослитиздат, 1959. Т. 1. 480 с.

12. Лепешинская А., Добрынин Б. Волга. М., 1911. 294 с.

13. Коринфский А.А. Волга: сказания, картины и думы. М., 1903.158 с.

THE FOREIGN IN RUSSIAN LITERATURE AND JOURNALISM OF THE 19TH CENTURY: PERCEPTION OF THE POLYETHNOCONFESSIONAL VOLGA REGION IN THE WORKS OF RUSSIAN WRITERS

Imagologiya i komparativistika - Imagology and Comparative Studies, 2017, 8, pp. $142-157$. DOI: $10.17223 / 24099554 / 8 / 8$

Ludmila N. Sarbash, Chuvash State University (Cheboksary, Russian Federation).

E-mail: sarbash.lu@yandex.ru

Keywords: foreign, Russian literature of 19th century, creative perception, polyethnoconfessional Volga region, ethnography, local cultures.

The article analyses the foreign in Russian literature and journalism of the 19th century, the reception of the polyethnoconfessional Volga region in the characteristic manifestations of ethnography. The representation of the non-Russian, the archetypes of the national consciousness, customs and rituals of the Volga peoples in the depiction of Russian writers is studied.

The imagology of the Russian space, "psychological ethnography" (N. Nadezhdin) is fully manifested in nineteenth-century Russian literature which participates in the "assimi- 
lation" of the foreign soil of Russian reality. The specifics of the way of life, the ritual aspect of life, the religious mythological belief, the poetic creativity of the non-Russian peoples of the Volga region - the Chuvash, the Mordvins, the Votyaks (Udmurts), the Cheremis (Mari), the Tatars, the Bashkirs, the Little Russians ("Zaporozhye people beyond the Volga"), the Germans, the Kalmyks - appears in the work of Russian writers in numerous notes, in literary and ethnographic articles, in the ideological and artistic system of works by V.V. Izmaylov, A.F. Voyeikov, M.I. Nevzorov, D.V. Davydova, F.N. Glinka, A.F. Raevsky, T.S. Belyaeva, P.M. Kudryashev, I.I. Zheleznov, I.V. Selivanov, N.Ya. Aristov, A.F. Leopoldov, A.S. Pushkin, A.I. Herzen, I.I. Lazhechnikov, S.T. Aksakov, I.S. Aksakov, V.I. Dahl, M.V. Avdeev, A.K. Tolstoy, P.I. MelnikovPechersky, A.A. Potekhin, A.N. Ostrovsky, S.V. Maksimov, A.F. Pisemsky, F.D. Nefedov, N.S. Leskov, M.E. Saltykov-Shchedrin, G.I. Uspensky, K.K. Sluchevsky, N.D. Teleshov, L.N. Tolstoy, D.N. Mamin-Sibiryak, N.G. Garin-Mikhailovsky, V.G. Korolenko, V.I. Nemirovich-Danchenko, A.A. Korinfsky, A.P. Valuev and many others.

The representation of the foreign in the Russian literary process of the nineteenth century appears in several directions: non-Russian as a religious mythological ethnography rituals and customs, religious mythological beliefs; non-Russian in the typical characterology of time as social ethnography; non-Russian as a comprehension of the spiritual and moral experience and the value world of other nations. An alien picture of life is presented by Russian writers through archetypes of national consciousness, Russian and non-Russian folklore: legends, historical and toponymic legends, ritual songs show the ethno-cultural characteristics, spiritual and moral ideals of numerous peoples of the Volga region.

\section{References}

1. Chirikov, E.N. (1916) Sobranie sochineniy: v 17 t. [Works: in 17 vols]. Vol. 16. Moscow: Moskovskoe knigoizdatel'stvo. pp. 94-120.

2. Bakhtin, M.M. (1986) Estetika slovesnogo tvorchestva [Aesthetics of verbal creativity]. Moscow: Iskusstvo.

3. Rakhimkulov, M. (1989) Kommentarii k "Bashkirskoy rusalke" [Commentaries on “The Bashkir Mermaid"]. In: Rakhimkulov, M. (ed.) Bashkiriya v russkoy literature: $v 6 t$. [Bashkiria in Russian literature: in 6 vols]. Vol. 1. Ufa: Bashk. kn. izd-vo.

4. Dahl, V. (Kazak Luganskiy). (1897) Polnoe sobranie sochineniy [Complete Works]. Vol. 7. St. Petersburg; Moscow: Izd. t-va M.O. Vol'f.

5. Kudryashev, P.M. (1828) Pesn' bashkirtsa posle srazheniya [Song of a Bashkir after the battle]. Vestnik Evropy. 15. pp. 198-201.

6. Belyaev, T.S. (1971) Pesn' Kuraycha Rifeyskikh gor [Song of the Quraysa of the Riphean mountains]. In: Lotman, Yu.M. (ed.) Poety 1790-1810-kh godov [Poets of the 1790s-1810s]. Leningrad: Sovetskiy pisatel'.

7. Maksimov, S.V. (1873) Kray kreshchenogo sveta: $v 4$ ch. [The region of baptized world: in 4 parts]. Pt. 2. St. Petersburg: Izd. t-va “Obshchestvennaya pol'za.

8. Garin-Mikhaylovskiy, N.G. (1958) Sobranie sochineniy: $v 5 t$. [Works: in 5 vols]. Vol. 4. Moscow: Gos. izd-vo khudo-zhestv. lit.

9. Nemirovich-Danchenko, V.I. (1902) Velikaya reka. Kartiny iz zhizni i prirody na Volge [A great river. Pictures from life and nature on the Volga]. St. Petersburg: Izd. P.P. Soykina. 
10. Sarbash, L.N. (2016) German world of the Volga: image of Sarepta in "A Journey to the Midday Russia" by V. Izmailov. Filologicheskie nauki. Voprosy teorii i praktikiPhilological Sciences. Issues of Theory and Practice. 6:2. pp. 25-27. (In Russian).

11. Zhukovsky, V.A. (1959) Sobranie sochineniy: v 4 t. [Works: in 4 vols]. Vol. 1. Moscow: Goslitizdat.

12. Lepeshinskaya, A. \& Dobrynin, B. (1911) Volga [The Volga]. Moscow: Tip. t-va I.D. Sytina.

13. Korinfskiy, A.A. (1903) Volga: skazaniya, kartiny i dumy [The Volga: legends, pictures and thoughts]. Moscow: M.V. Klyukin. 